\title{
Water Quality and Plant Species Composition of Selected Sites within Chemususudam, Baringo County, Kenya
}

\section{Manohar S, Kitur EL and Kibet FC*}

Department of Environmental Sciences, Kenyatta University, Nairobi, Kenya

\begin{abstract}
Aquatic plant species and physico-chemical parameters of Chemususu Dam, Baringo County, Kenya were studied from differernt sampling stations D1, D2 and D3 situated in north west, south and north east directions of the dam respectively. There are only 19 phytoplankton species (Nitzchia $s p$, Diatoma vulgare, Synedra sp, Navicula $s p$, Oedogonium sp. Spirogyra $s p$, Closterium sp, Chodatella $s p$, Chlorella $s p$, Crucigenia sp, Pleurotaenium $s p$, Gonatozygon sp, Closterium aciculare, Pediastrum sp. Scenedesmus $s p$, Cosmarium $s p$, Geminella sp, Ceratium $s p$, Peridinium $s p$ ). The common species present in all the sites were: Nitzchia sp, Scenedesmus sp, Spirogyra sp, Chlorella $s p$, Ceratium $s p$, Peridinium sp, Gonatozygon $s p$, Synedra $s p$, and Navicula sp. In D1, Diatoma vulgare and Cosmarium $s p$ in D2 were specific in these sites. Three emergent aquatic angiosperm species were present; Typha latifolia and Portulaca oleracea are present at D1 site, while Aponogetona froviolaceus together with $T$. latifolia and $P$. oleracea are at $D 2$ site along the periphery of thiswater body. It is noticed that D3 site these angiosperms are completely absent due to rocky habitat. Cynophytes are not visible due to flow nutrient level and dam is also less than one year old. The average values of chemical parameters $(\mathrm{mg} / \mathrm{l})$ are; nitrates $4.42 \pm 0.07$, phosphates $4.23 \pm 1.17$, sulphates $3.48 \pm 0.22$, chloride $2.73 \pm 0.57$, carbonates $8.6 \pm 0.7$ and physical parameters such as conductivity $81.16 \mu \mathrm{S} / \mathrm{cm}$, dissolved oxygen is $4.2 \mathrm{mg} / \mathrm{l}, \mathrm{pH} 6.77$, turbidity $3.12 \mathrm{NTU}$ and temperature is less than $21.5^{\circ} \mathrm{C}$ within the dam at an altitude of 2480 meters above the sea level. Based on current physico-chemical parameters and species composition, it is concluded that the water quality parameters of the dam meet the requirements for human consumption.
\end{abstract}

Keywords: Water quality; Phytoplanktons; Aquatic macrophytes; Chemususu Dam

\section{Introduction}

Phytoplanktons inhabit the upper euphotic layer of water body and cause considerable turbidity if density increases [1]. Diversity of algal species and their high densities indicate warning signs of deteriorating water conditions [2]. All categories of hydrophytes play a significant role in an aquatic ecosystem and their stratification (i) free floating, (ii) attached-floating (iii) submerged and (iv) emergent species depend on the interaction of biological, physical, chemical characteristic of water and other environmental variables such as light intensity, duration and quality; temperature fluctuations, intensity of turbulent mixing, benthic feeders and seasonal fluctuations [3]. Nutrient enrichment also affects the composition and productivity of phytoplankton and other aquatic angiosperms which alter the ecosystems function and structure $[4,5]$. Phytoplankton succession depends particularly on light, temperature and nutrient availability [4].

In an eutrophic lake or dam, there is an increase in productivity of cynobacteria which strongly aggravate water quality and out flowing river because of the potential threat from toxins to aquatic environment, human health and life [6]. Freshwater micro plankton comprise of species with short life cycles, strongly affected by seasonal fluctuations and mortality factors through parasitism and by zooplankton. Microalgae significantly contribute to assessing eutrophication levels in aquatic habitats [7]. Hydrophytes are important in food chain, provide microhabitats, protection against predators, substrates for aquatic organisms including invertebrates, algae and bacteria which contribute to nutrient cycling [8]. In tropical countries, eutrophication is taking place as a result of nutrient inflows from human activities in watersheds [9]. Urban reservoirs with increasing eutrophication of water bodies often results in high number of macrophytes [10]. The nutrient level and the size affect the level of composition and extent of occurrence of macrophytes [11].

\section{Materials and Methods}

\section{Study area}

The study was carried out at Chemususu Dam which is located within Lembus forest (Figure 1) in Baringo County, Kenya. The dam is situated at a latitude of $0^{\circ} 05^{\prime} 16.34^{\prime \prime}$ north; Longitude of $35^{\circ} 37^{\prime} 59.00^{\prime \prime}$ east and at an altitude of 2480 meters above the sea level. The capacity of this dam is 10.94 cubic meters of water and covers approximately 95 hectares.

\section{Data collection and analysis}

Macrophytes were collected from three sampling stations D1, D2 and D3 of the dam. To keep track of macrophytes along the dam, field notes corresponding to each plant was recorded including date, location, flower colour, plant size and habitat information. Whole plant or shoots of macrophytes along the periphery of the dam were randomly collected at each sampling point and placed in clear polythene bags. Water samples for phytoplankton identification were scoped 20 $\mathrm{cm}$ below the surface of water using a 2 litre water sampler, passed through plankton net and transferred into $50 \mathrm{ml}$ plastic containers. The samples were preserved using $4 \%$ formalin [2] and then transported to the laboratory. The water samples for phytoplankton identification were mixed and a drop was placed in the slide for observation using

*Corresponding author: Kibet FC, Department of Environmental Sciences, Kenyatta University, PO Box 43844-00100, Nairobi, Kenya, Tel: +254738974888; E-mail: prof.dr.smanohar@gmail.com

Received July 13, 2016; Accepted July 28, 2016; Published July 30, 2016

Citation: Manohar S, Kitur EL, Kibet FC (2016) Water Quality and Plant Species Composition of Selected Sites within Chemususudam, Baringo County, Kenya. J Environ Anal Toxicol 6: 390. doi :10.4172/2161-0525.1000390

Copyright: () 2016 Manohar S, et al. This is an open-access article distributed under the terms of the Creative Commons Attribution License, which permits unrestricted use, distribution, and reproduction in any medium, provided the original author and source are credited. 
Citation: Manohar S, Kitur EL, Kibet FC (2016) Water Quality and Plant Species Composition of Selected Sites within Chemususudam, Baringo County, Kenya. J Environ Anal Toxicol 6: 390. doi :10.4172/2161-0525.1000390

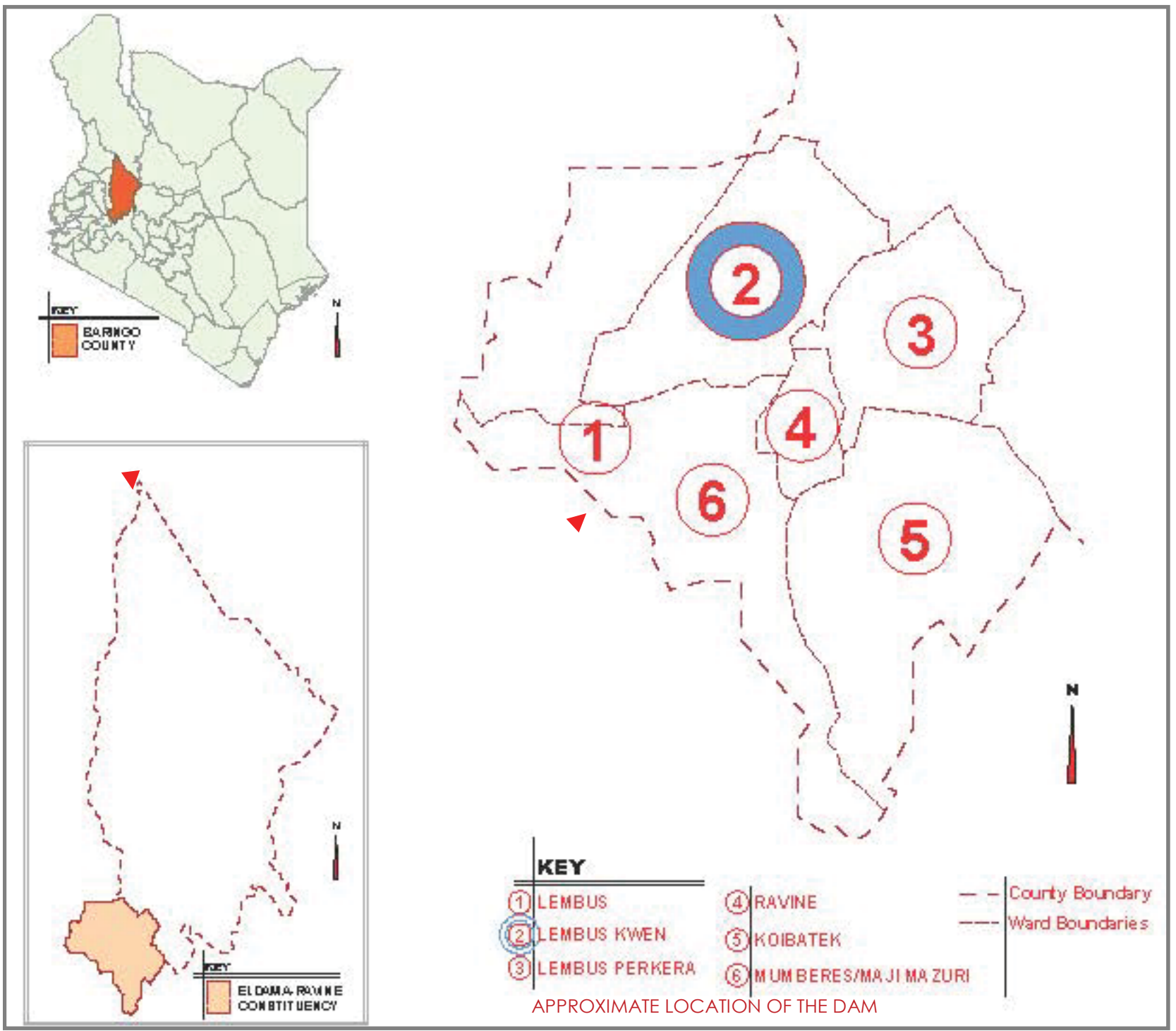

Figure 1: Map of Kenya showing Chemususu Dam in Baringo County, Eldama-Ravine Constituency, LembsKwen ward [29].

an Optica compound microscope at x10 magnification. Phytoplankton species were confirmed using taxonomic keys [12-14].

Water samples for measuring the physic-chemical parameters were collected from six sampling points made up of two inflowing river $(\mathrm{C} 1$ and $\mathrm{C} 2$ ), dam (C3) and out flowing river (C4). Sawich and Barain rivers were purposely selected because they are the main rivers flowing into the dam. Sampling points were randomly selected at approximately $100 \mathrm{~m}$ to the inlet in Sawich river (C1) and $40 \mathrm{~m}$ (C2) in Barain river in accessible areas closest to the dam inlets to get a representative sample of the water getting into the dam. Within the dam, two points were randomly selected along the accessible periphery. Sampling point D1 was between the two inlets in the Northward side while D2 was far from the inlets towards the Eastern side. Sampling point D3 was along the dam wall on the Southern part and this point was far from influence of inlets, animals and bank erosion (Figure 2).

Physical parameters were determined in the field during sample collection using instruments which were calibrated before each sampling trip [2]. Dissolved oxygen and temperature were measured using a dissolved oxygen probe (model Q628721 M.R.C) with a temperature compensation at $25^{\circ} \mathrm{C}, \mathrm{pH}$ using a $\mathrm{pH}$ meter probe (model Q640629 HANNA), Conductivity was measured with a conductivity meter probe (HI 9033 HANNA) with temperature compensation at $25^{\circ} \mathrm{C}$ and turbidity meter model number $(2100 \mathrm{P}$ $\mathrm{HACH}$ ) was used to measure turbidity. Water samples were collected $20 \mathrm{~cm}$ below the water surface using a water scooper and transferred to clean labelled plastic bottles at each sampling station. Water samples for chemical analysis were then fixed using 0.2 $\mathrm{M} \mathrm{H}_{2} \mathrm{SO}_{4}$ and firmly corked. They were kept in an ice box ready to be transported to the laboratory. Nitrates, Phosphates and Sulphates were determined by calorimetric method using UV/VIS spectroscopy machine T80+ [2]. Titration method was used to get the concentration of Carbonates and Chlorides [2]. Carbonates were determined using $0.02 \mathrm{~N}$ sulphuric acid and mixed bromocressol green indicator and calculated as $\mathrm{mg} \mathrm{L}^{-1} \mathrm{CaCO}_{3}$ [2]. 
Citation: Manohar S, Kitur EL, Kibet FC (2016) Water Quality and Plant Species Composition of Selected Sites within Chemususudam, Baringo County, Kenya. J Environ Anal Toxicol 6: 390. doi :10.4172/2161-0525.1000390

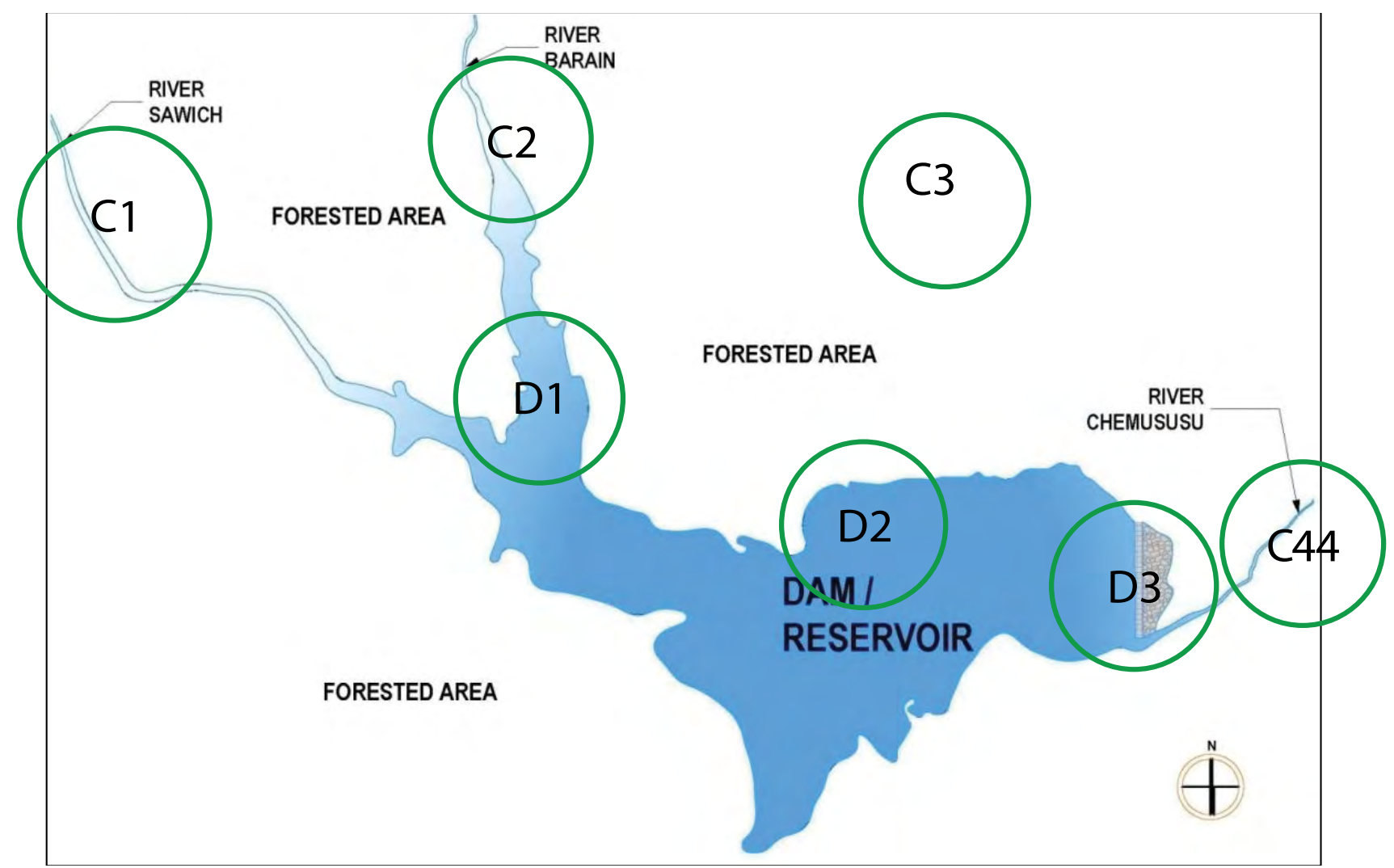

Figure 2: Shows sampling stations for dam, upstream and downstream rivers during sampling period August 2014 to January 2015.

\section{Results and Discussion}

\section{Physico-chemical parameters}

Water quality was determined by measuring the temperature, $\mathrm{pH}$, conductivity, turbidity, dissolved oxygen, nitrates, phosphates, sulphates, chlorides and carbonates on a monthly basis for six months.

Variations in water temperature are influenced by meteorological aspects such as humidity, solar radiation and rainfall [15]. The mean temperatures ranged from $17.02 \pm 1.10{ }^{\circ} \mathrm{C}$ in station $\mathrm{C} 1$ to $21.48 \pm$ $0.61{ }^{\circ} \mathrm{C}$ in $\mathrm{C} 3$ (Table 1). Using paired t-test, the mean temperature recorded was significantly different between temperature in upstream rivers and the dam; and between upstream rivers and out flowing river with $\mathrm{C} 1$ and $\mathrm{C} 3(\mathrm{P}=0.001, \mathrm{~T}=-7.889) ; \mathrm{C} 2$ and $\mathrm{C} 3(\mathrm{P}=0.001$, $\mathrm{T}=-7.613)$; $\mathrm{C} 1$ and $\mathrm{C} 4(\mathrm{P}=0.002, \mathrm{~T}=-5.665)$, and between $\mathrm{C} 2$ and $\mathrm{C} 4(\mathrm{P}=0.004, \mathrm{~T}=-5.013)$. The interaction of the calm water with ambient temperature due to solar radiation could also have led to the increase in temperature in the dam.

The $\mathrm{pH}$ values were within the normal range during the study period. These values ranged from 6.2 to 7.71 in $\mathrm{C} 1,6.4$ to 7.54 in $\mathrm{C} 2$, 6.47 to 7.34 in $\mathrm{C} 3$ and 6.54 to 7.67 in C4. pH levels within the dam may be due to deposition of organic matter into water due to surface runoff from forest and farmlands as well as the submerged vegetation during infilling of the dam. The partial decomposition by bacteria and fungi of this organic matter produce various organic acids that are capable of lowering the $\mathrm{pH}$.

Turbidity exhibited wide variation during the study period. Paired t-test showed a significant difference between turbidity of inflowing

\begin{tabular}{|c|c|c|c|c|}
\hline Parameter & C1 & C2 & $\begin{array}{c}\text { C3 (D1, D2, } \\
\text { D3) }\end{array}$ & C4 \\
\hline & & $17.05 \pm$ & & \\
Temperature $\left({ }^{\circ} \mathrm{C}\right)$ & $17.02 \pm 1.10$ & 1.15 & $21.48 \pm 0.61$ & $20.48 \pm$ \\
pH & $6.88 \pm 0.24$ & $6.89 \pm 0.22$ & $6.77 \pm 0.12$ & 0.50 \\
Turbidity $\left(\mathrm{mg} \mathrm{L}^{-1}\right)$ & $94.82 \pm 16.78$ & $44.28 \pm$ & $3.12 \pm 0.17$ & $6.87 \pm 0.16$ \\
Conductivity $(\mu \mathrm{S} / \mathrm{cm})$ & $67.48 \pm 4.10$ & 6.34 & $81.16 \pm 4.13$ & $4.15 \pm 0.63$ \\
Dissolved Oxygen & $6.09 \pm 0.33$ & $63.67 \pm$ & $4.2 \pm 0.76$ & $79.2 \pm 3.66$ \\
$\left(\mathrm{mg} \mathrm{L}^{-1}\right)$ & & 4.60 & & $4.73 \pm 0.76$ \\
\hline
\end{tabular}

Table 1: Mean values of physical parameters recorded in Chemususu Dam, inlet and outlet of rivers during the study period (August 2014 to January 2015).

rivers; $\mathrm{C} 1$ and $\mathrm{C} 2(\mathrm{P}=0.007, \mathrm{~T}=4.401)$, inflowing rivers and dam; $\mathrm{C} 1$ and C3 $(\mathrm{P}=0.003, \mathrm{~T}=5.518), \mathrm{C} 2$ and $\mathrm{C} 3(\mathrm{P}=0.001, \mathrm{~T}=6.626)$, and between inflowing rivers and out flowing river; $\mathrm{C} 1$ and $\mathrm{C} 4(\mathrm{P}=0.003, \mathrm{~T}=5.489)$, and $\mathrm{C} 2$ and $\mathrm{C} 4(\mathrm{P}=0.001, \mathrm{~T}=6.814)$. The low levels of turbidity in dam could be attributed to the slow movement of water which allows for the settling of suspended particles and silt. The forest surrounding the dam could also have contributed to reduced shoreline erosion by binding the soil particles.

The highest mean conductivity recorded was $81.16 \pm 4.13 \mu \mathrm{S} / \mathrm{cm}$ in $\mathrm{C} 3$ and the lowest was $63.67 \pm 4.60 \mu \mathrm{S} / \mathrm{cm}$ in C2 (Table 1). Using paired t-test, significant difference in conductivity was found between upstream rivers and dam; $\mathrm{C} 1$ and $\mathrm{C} 3(\mathrm{P}=0.003, \mathrm{~T}=-5.596), \mathrm{C} 2$ and C3 $(\mathrm{P}=0.000, \mathrm{~T}=-8.443)$, and between upstream river and out flowing river; $\mathrm{C} 1$ and $\mathrm{C} 4(\mathrm{P}=0.005, \mathrm{~T}=-4.677), \mathrm{C} 2$ and $\mathrm{C} 4(\mathrm{P}=0.002, \mathrm{~T}=-6.277)$. Variations in conductivity are due to duration of standing water, dissolved solids from catchment area, dilution with rainfall and ion exchange between sediments and water in dam [4], internal loadings of 
vegetation and soil [16] and the geology of the catchment area $[17,18]$. The conductivity in $\mathrm{C} 3$ could be as a result of residence time which leads to ion exchange between sediments and water. The submerged vegetation and soil could also have led to the increase in conductivity.

Dissolved oxygen levels measured during the study period showed wide variations. In $\mathrm{C} 1$ the levels in $\mathrm{mg} / \mathrm{l}$ ranged from 5.3 to $7.34 ; 5.7$ to 6.4 in $\mathrm{C} 2 ; 1.7$ to 6.46 in $\mathrm{C} 3$ and 2.2 to 6.9 in $\mathrm{C} 4$ was recorded during the study period. Using paired t-test, there was significant difference in dissolved oxygen between sites $\mathrm{C} 3$ and $\mathrm{C} 4(\mathrm{P}=0.001, \mathrm{~T}=-6.944)$. Low levels of DO in Chemususu dam were recorded during the entire study period. This could be attributed to reduced flow rate which reduces turbulence causing aeration. In addition, the low dissolved oxygen may be as a result of decomposition of submerged vegetation which was not deforested during construction of the dam. Low levels of macrophytes along the periphery of the dam mean less photosynthesis which could also have contributed to low dissolved oxygen levels (Table 2).

A wide variation in nitrate nitrogen $\left(\mathrm{NO}_{2}-\mathrm{N}\right)$ levels was recorded during the study period and ranged from $2.12 \mathrm{mg} \mathrm{L}^{-1}$ to $8.71 \mathrm{mg} \mathrm{L}^{-1}$ in $\mathrm{C} 1 ; 1.17 \mathrm{mg} \mathrm{L}^{-1}$ to $9.25 \mathrm{mg} \mathrm{L}^{-1}$ in $\mathrm{C} 2 ; 4.24 \mathrm{mg} \mathrm{L}^{-1}$ to $4.60 \mathrm{mg} \mathrm{L}^{-1}$ in $\mathrm{C} 3$ and $4.01 \mathrm{mg} \mathrm{L}^{-1}$ to $4.84 \mathrm{mg} \mathrm{L}^{-1}$ in C4. The mean concentration of nitrates at different sites showed no significant difference between sites $(\mathrm{P}>0.05)$. Changes in the levels of nitrate in water are caused by phytoplankton uptake and de nitrification by bacteria $[19,20]$, discharge of sewerage [21], agricultural activities [20], metabolic waste, excretory products and decaying organic matter [22]. The high mean concentration recorded at $\mathrm{C} 1\left(5.26 \pm 1.16 \mathrm{mg} \mathrm{L}^{-1}\right)$ may be due to use of fertilizers which get leached and eroded to streams. It was also observed that high concentrations occurred during rainy months. The low levels in $\mathrm{C} 4$ compared to inflowing rivers; $\mathrm{C} 1$ and $\mathrm{C} 2$ may be as a result of uptake by phytoplankton in the dam.

Total phosphate (TP) levels varied from $1.35 \mathrm{mg} \mathrm{L}^{-1}$ to $5.39 \mathrm{mg} \mathrm{L}^{-1}$ in $\mathrm{C} 1 ; 1.69 \mathrm{mg} \mathrm{L}^{-1}$ to $7.78 \mathrm{mg} \mathrm{L}^{-1}$ in $\mathrm{C} 2,1.45 \mathrm{mg} \mathrm{L}^{-1}$ to $8.79 \mathrm{mg} \mathrm{L}^{-1}$ in C3 and $0.72 \mathrm{mg} \mathrm{L}^{-1}$ to $7.73 \mathrm{mg} \mathrm{L}^{-1}$ in C4. Paired t-test showed that there was significant difference in phosphate levels of both upstream rivers Sawich (C1) and Barain (C2) $(\mathrm{P}=0.025, \mathrm{~T}=-3.16)$, and between dam (C3) and out flowing river $(\mathrm{C} 4)(\mathrm{P}=0.014, \mathrm{~T}=3.718)$. Phosphates in surface water arise from run-off from agricultural farms $[23,24]$, municipal sewage in which mostly phosphate will be as a result of domestic detergent and silage effluents $[19,25]$. However, a reduced level of phosphate in dam is as a result of uptake by phytoplankton and adsorption to particulate matter and subsequent sedimentation [19].

Sulphates level ranged from $4.42 \mathrm{mg} \mathrm{L}^{-1}$ to $8.43 \mathrm{mg} \mathrm{L}^{-1}$ in $\mathrm{C} 1,4.51$ $\mathrm{mg} \mathrm{L}^{-1}$ to $8.51 \mathrm{mg} \mathrm{L}^{-1}$ in $\mathrm{C} 2,2.93 \mathrm{mg} \mathrm{L}^{-1}$ to $4.48 \mathrm{mg} \mathrm{L}^{-1}$ in $\mathrm{C} 3$ and 2.72 $\mathrm{mg} \mathrm{L}^{-1}$ to $3.97 \mathrm{mg} \mathrm{L}^{-1}$ in $\mathrm{C} 4$. The paired t-test results showed that there was significant difference in sulphates between upstream rivers and dam; $\mathrm{C} 1$ and $\mathrm{C} 3(\mathrm{P}=0.001, \mathrm{~T}=2.14), \mathrm{C} 2$ and $\mathrm{C} 3(\mathrm{P}=0.002, \mathrm{~T}=6.79)$, and between upstream rivers and out flowing river; $\mathrm{C} 1$ and $\mathrm{C} 4(\mathrm{P}=0.001$, $\mathrm{T}=7.46)$ and between $\mathrm{C} 2$ and $\mathrm{C} 4(\mathrm{P}=0.004, \mathrm{~T}=5.04)$. Sources of sulphate in water include leaching from soil, industrial discharge, decaying animal and plant matter, chemical products including ammonium sulphate fertilizers and treatment of water with aluminium sulphate (alum) also introduces sulphate into a water supply [26]. The mean chloride level was $2.33 \pm 0.42 \mathrm{mg} \mathrm{L}^{-1}$ in $\mathrm{C} 1,2.50 \pm 0.34 \mathrm{mg} \mathrm{L}^{-1}$ in $\mathrm{C} 2$, $2.73 \pm 0.57 \mathrm{mg} \mathrm{L}^{-1}$ in $\mathrm{C} 3$ and $2.17 \pm 0.3 \mathrm{mg} \mathrm{L}^{-1}$ in C4. Paired t-test results showed no significant difference in chloride levels between different sites $(\mathrm{P}>0.05)$. Increased levels of chloride in water are as a result of fertilizer, municipal and domestic sewage $[21,27]$. Water softeners, animal feed additives, pesticides, concentration and dissolution of salts resulting from irrigation with deep groundwater also contribute to increase in chloride levels of surface water [28].
Water analysis showed that carbonates levels in upstream rivers ranged from $6 \mathrm{mg} \mathrm{L}^{-1}$ to $8 \mathrm{mg} \mathrm{L}^{-1}$ and $4 \mathrm{mg} \mathrm{L}^{-1}$ to $5 \mathrm{mg} \mathrm{L}^{-1}$ in $\mathrm{C} 1$ and $\mathrm{C} 2$ respectively; $5.3 \mathrm{mg} \mathrm{L}^{-1}$ to $11.7 \mathrm{mg} \mathrm{L}^{-1}$ in $\mathrm{C} 3$ and $5 \mathrm{mg} \mathrm{L}^{-1}$ to $11 \mathrm{mg} \mathrm{L}^{-1}$ in C4. Paired t-test showed that there was significant difference in carbonates between upstream rivers; $\mathrm{C} 1$ and $\mathrm{C} 2(\mathrm{P}=0.001, \mathrm{~T}=6.325)$; upstream river Barain and dam; $\mathrm{C} 2$ and $\mathrm{C} 3(\mathrm{P}=0.006, \mathrm{~T}=-4.57)$ and between $\mathrm{C} 2$ and $\mathrm{C} 4$ $(\mathrm{P}=0.002,-5.70)$. Levels of carbonates in water depends on weathering process in catchments, rate of photosynthesis, respiration [4] and organic decomposition [25] in water. The carbonates at $8.7 \mathrm{mg} \mathrm{L}^{-1}$ and $\mathrm{pH}$ of 6.77 could be due to respiration and the decomposition of several acres of forest cover which was submerged during construction since it was not cleared.

\section{Comparison with drinking water standards}

The level of turbidity, conductivity, nitrates, sulphates, $\mathrm{pH}$ and chlorides in all the sites are within the required drinking water standards according to $[19,20]$. However, phosphate levels in all the sites are higher than the recommended $2.2 \mathrm{mg} / \mathrm{l}$ by [19].

\section{Plant species composition}

During the study period, a total of 19 phytoplankton species were identified within Chemususu Dam belonging to three divisions: Chlorophyta, Bacillariophyta, and Dinophyta (Table 1). There were 2 sp, 4 sp and 13 sp belonging to Dinophyta, Bacilariophyta and Chlorophyta respectively. It was observed that the frequency of species was less than five from the month of August to October 2014 but the frequency increased from the month of November 2014 to January 2015 which recorded 14 species in D1; 13 species in D2 and 9 species in D3. Phytoplankton composition depends on seasonal dynamics regulated by changes in nutrient availability, temperature, light, intensity of turbulent mixing, benthic feeders, altitude and seasons and impact of rain [6]. According to [11], increase in water temperature influence algal succession progression from Bacillariophyceae to Chlorophyceae to Cynophyceae. Ref. [7] recorded a decrease in the number of phytoplankton species and their growth during rainy season (Table 3).

During the study, it was observed that in the rainy periods the phytoplankton species were low in numbers during August, September and October. This could be attributed the disturbances by rainfall and may be the low levels of dissolved oxygen whose averages were $3.4 \mathrm{mg} / \mathrm{l}, 2.9 \mathrm{mg} / \mathrm{l}$ and $3.2 \mathrm{mg} / \mathrm{l}$ for sampling stations D1, D2 and D3 respectively. An increase in the number of species from November to January could be due to increase in temperature and slightly high dissolved oxygen levels [7]. Nutrients also are ending in this water reservoir due to runoff from agricultural farms, surrounding forest and its decomposing organic matter during short and long rainy seasons. There were three species of aquatic macrophytes along the periphery of Chemususu Dam. Typha latifolia is emergent and present along sampling station D1 and D2. Aponogetona froviolaceus is attached submerged hydrophyte found in sampling point D2 and Portulaca oleracea was present in sampling station D1 and D2 respectively.

Typha latifolia is a dominant swamp plant which covered small sections along the periphery of the dam except the dam wall. Aponogetona froviolaceusis a perennial plant that inhabits running and stagnant water. It leaves can either be submerged or float depending on the depth of water. It grows close or in areas sediment accumulates and withstands dry spells due to its dormant tubers [29]. Portulaca oleracea, is a low growing succulent plant which was found along the periphery of the dam. It grows along streams, flood plains and swamps. The frequency of macrophytes is low within the dam due to its 1 year old establishment. It is expected that with time, there will be an increase in the number of species of angiosperms and algal flora (Table 4). 
Citation: Manohar S, Kitur EL, Kibet FC (2016) Water Quality and Plant Species Composition of Selected Sites within Chemususudam, Baringo County, Kenya. J Environ Anal Toxicol 6: 390. doi :10.4172/2161-0525.1000390

Page 5 of 6

\begin{tabular}{|c|c|c|c|}
\hline Parameter & C1 & C2 & C3 (D1, D2, D3) \\
\hline Nitrate nitrogen $\left(\mathrm{mg} \mathrm{L}^{-1}\right)$ & $5.26 \pm 1.16$ & $5.20 \pm 1.26$ & $4.42 \pm 0.07$ \\
Total phosphates $\left(\mathrm{mg} \mathrm{L}^{1}\right)$ & $3.34 \pm 0.72$ & $4.5 \pm 0.96$ & $4.23 \pm 1.17$ \\
Sulphates $\left(\mathrm{mg} \mathrm{L}^{-1}\right)$ & $7.2 \pm 0.66$ & $6.21 \pm 0.62$ & $3.48 \pm 0.22$ \\
Chlorides $\left(\mathrm{mg} \mathrm{L}^{-1}\right)$ & $2.33 \pm 0.42$ & $2.5 \pm 0.34$ & $3.58 \pm 1.15$ \\
Carbonates $\left(\mathrm{mg} \mathrm{L}^{-1}\right)$ & $6.8 \pm 0.4$ & $4.17 \pm 0.17$ & $3.3 \pm 0.20$ \\
\hline
\end{tabular}

Table 2: Mean values of chemical parameters recorded in Chemususu Dam and rivers during the study period (August 2014 to January 2015 ).

\begin{tabular}{|c|c|c|c|}
\hline PHYTOPLANKTONS & (D1) & (D2) & (D3) \\
\hline $\begin{array}{l}\text { Bacillariophyta } \\
\text { Nitzchiasp } \\
\text { Diatomavulgare } \\
\text { Synedrasp } \\
\text { Naviculasp } \\
\text { Chlorophyta } \\
\text { Oedogoniumsp } \\
\text { Spirogyra sp } \\
\text { Closteriumsp } \\
\text { Chodatellasp } \\
\text { Chlorella sp } \\
\text { Crucigeniasp } \\
\text { Pleurotaeniumsp } \\
\text { Gonatozygonsp } \\
\text { Closteriumaciculare } \\
\text { Pediastrumsp } \\
\text { Scenedesmussp } \\
\text { Cosmariumsp } \\
\text { Geminellasp } \\
\text { Dinophyta } \\
\text { Ceratiumsp } \\
\text { Peridiniumsp }\end{array}$ & $\begin{array}{l}(+) \\
(+) \\
(+) \\
(+) \\
(+) \\
(+) \\
(+) \\
(+) \\
(+) \\
(+) \\
(+) \\
(+) \\
(+) \\
(-) \\
(-) \\
(-) \\
(-) \\
(+) \\
(+)\end{array}$ & $\begin{array}{l}(+) \\
(+) \\
(+) \\
(+) \\
\\
(+) \\
(+) \\
(-) \\
(+) \\
(+) \\
(+) \\
(+) \\
(+) \\
(+) \\
(-) \\
(+) \\
(+) \\
(+) \\
(-) \\
(+)\end{array}$ & $\begin{array}{l}(+) \\
(+) \\
(+) \\
(+) \\
(-) \\
(+) \\
(-) \\
(-) \\
(+) \\
(-) \\
(+) \\
(+) \\
(-) \\
(+) \\
(+) \\
(-) \\
(+) \\
(+) \\
(+)\end{array}$ \\
\hline
\end{tabular}

KEY: (+) Present (-) Absent

Table 3: List of phytoplankton species composition between August 2014 and January 2015 within Chemususu Dam, Baringo County, Kenya.

\begin{tabular}{|c|c|c|c|}
\hline & Sampling station D1 & Sampling station D2 & Sampling station D3 \\
\hline \multicolumn{4}{|c|}{ 18th August 2014} \\
\hline - & Naviculasp & $\begin{array}{ll}- & \text { Ceratiumsp } \\
\text { - } & \text { Naviculasp }\end{array}$ & $\begin{array}{ll}\text { - } & \text { Ceratiumsp } \\
\text { - } & \text { Naviculasp }\end{array}$ \\
\hline \multicolumn{4}{|c|}{ 13th September 2014} \\
\hline$\bullet$ & $\begin{array}{l}\text { Naviculasp } \\
\text { Synedrasp } \\
\text { Ceratiumsp }\end{array}$ & $\begin{array}{l}\text { - } \quad \text { Ceratiumsp } \\
\text { - } \quad \text { Naviculasp }\end{array}$ & $\begin{array}{ll}\text { - } & \text { Spirogyra sp } \\
\text { - } & \text { Neratiumsp } \\
& \text { Naviculasp }\end{array}$ \\
\hline \multicolumn{4}{|c|}{ 18th October 2014} \\
\hline : & $\begin{array}{l}\text { Naviculasp } \\
\text { Synedrasp } \\
\text { Ceratiumsp } \\
\text { Chodatellasp } \\
\text { Chlorella } s p\end{array}$ & $\begin{array}{ll}\text { - } & \text { Spirogyra sp } \\
\text { - } & \text { Scenedesmussp } \\
\text { - } & \text { Nitziculasp } \\
& \text { Nitzchiasp }\end{array}$ & $\begin{array}{l}\text { Naviculasp } \\
\text { Synedrasp } \\
\text { Spirogyra sp }\end{array}$ \\
\hline \multicolumn{4}{|c|}{ 15th Nov 2014} \\
\hline $\begin{array}{l}\cdot \\
. \\
. \\
.\end{array}$ & $\begin{array}{l}\text { Closteriumsp } \\
\text { Spirogyra sp } \\
\text { Peridiniumsp } \\
\text { Pediastrumsp } \\
\text { Naviculasp } \\
\text { Synedrasp }\end{array}$ & $\begin{array}{ll}\text { - } & \text { Peridiniumsp } \\
\text { - } & \text { Closteriumaciculare } \\
\text { - } & \text { Crucigeniasp } \\
\text { - } & \text { Spirogyra } s p \\
\text { - } & \text { Scenedesmussp } \\
& \text { Naviculasp }\end{array}$ & $\begin{array}{ll}\text { - } & \text { Peridiniumsp } \\
\text { - } & \text { Spirogyra } s p \\
\text { - } & \text { Gonatozygonsp } \\
\text { - } & \text { Scenedesmussp } \\
& \text { Naviculasp }\end{array}$ \\
\hline \multicolumn{4}{|c|}{ 16th December 2014} \\
\hline $\begin{array}{l}\cdot \\
. \\
. \\
. \\
. \\
. \\
.\end{array}$ & $\begin{array}{l}\text { Crucigeniasp } \\
\text { Spirogyra sp } \\
\text { Pleuritaeniumsp } \\
\text { Peridiniumsp } \\
\text { Gonatozygonsp } \\
\text { Scenedesmussp } \\
\text { Diatomavulgare } \\
\text { Naviculasp }\end{array}$ & $\begin{array}{ll}\text { - } & \text { Spirogyra sp } \\
\text { - } & \text { Oedogoniumsp } \\
\text { - } & \text { Peridiniumsp } \\
\text { - } & \text { Geminellasp } \\
\text { - } & \text { Cosmariumsp } \\
\text { - } & \text { Ceratiumsp } \\
\text { - } & \text { Nitzschiasp } \\
& \text { Synedrasp }\end{array}$ & $\begin{array}{l}\text { Chlorella sp } \\
\text { Geminellasp } \\
\text { Pediastrumsp } \\
\text { Peridiniumsp } \\
\text { Spirogyra sp } \\
\text { Nitzchiasp } \\
\text { Naviculasp }\end{array}$ \\
\hline \multicolumn{4}{|c|}{ 17th January 2015} \\
\hline
\end{tabular}


Citation: Manohar S, Kitur EL, Kibet FC (2016) Water Quality and Plant Species Composition of Selected Sites within Chemususudam, Baringo County, Kenya. J Environ Anal Toxicol 6: 390. doi :10.4172/2161-0525.1000390

Page 6 of 6

\begin{tabular}{|c|c|c|c|c|}
\hline 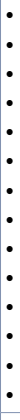 & $\begin{array}{l}\text { Spirogyra sp } \\
\text { Chodatellasp } \\
\text { Gonatozygonsp } \\
\text { Closteriumaciculare } \\
\text { Scenedesmussp } \\
\text { Pediastrumsp } \\
\text { Crucigeniatetrapedia } \\
\text { Closteriumsp } \\
\text { Ceratiumsp } \\
\text { Pleuritaeniumsp } \\
\text { Diatomavulgare } \\
\text { Naviculasp } \\
\text { Synedrasp } \\
\text { Nitzschiasp }\end{array}$ & $\begin{array}{l}\dot{0} \\
\text { : } \\
\text { : } \\
\text { : } \\
\text { : } \\
\text { : } \\
\text { : } \\
\text { : } \\
\text { : }\end{array}$ & $\begin{array}{l}\text { Closteriumsp } \\
\text { Chlorella sp } \\
\text { Spirogyra } s p \\
\text { Cosmariumsp } \\
\text { Peridiniumsp } \\
\text { Chodatellasp } \\
\text { Ceratiumsp } \\
\text { Gonatozygonsp } \\
\text { Pleuritaeniumsp } \\
\text { Geminellasp } \\
\text { Diatomavulgare } \\
\text { Synedrasp } \\
\text { Naviculasp }\end{array}$ & $\begin{array}{l}\text { Pediastrumsp } \\
\text { Peridiniumsp } \\
\text { Spirogyra sp } \\
\text { Gonatozygonsp } \\
\text { Ceratiumsp } \\
\text { Naviculasp } \\
\text { Geminellasp } \\
\text { Nitzschiasp } \\
\text { Synedrasp }\end{array}$ \\
\hline \multicolumn{5}{|c|}{ Angiosperms } \\
\hline - & $\begin{array}{l}\text { Typhalatifolia } \\
\text { Portulacaoleracea }\end{array}$ & $\bullet$ & $\begin{array}{l}\text { Typhalatifolia } \\
\text { Portulacaoleracea } \\
\text { Aponogetonafroviolaceus }\end{array}$ & $\begin{array}{l}\text { Angiosperms were absent on this site due to } \\
\text { constructed dam wall and rocky base/ platform. }\end{array}$ \\
\hline
\end{tabular}

Table 4: Aquatic plant species composition at three selected sampling sites along Chemususu Dam, Baringo County Kenya (August 2014 - January 2015).

\section{Conclusion}

There are 19 phytoplankton species identified during the study period. There are three emergent species of macrophytes Typha latifolia, Portulaca oleracea and Aponogetona froviolaceus present within the periphery of Chemususu Dam. Based on current species composition and physico-chemical parameters, the water quality of the dam can be used for domestic purposes and agricultural activities if chemical concentrations do not increase.

\section{References}

1. Madsen JD, Wersal RM (2012) A Review of Aquatic Plant Monitoring and Assessment Methods. Aquatic Ecosystem Restoration Foundation, Marietta, Atlanta.

2. APHA (1999) Standard Methods for the Examination of Water and Wastewater. American Public Health Association, Washington DC

3. Ndenda LA, Manohar S (2014) Bio concentration factor and Translocation Ability of Heavy Metals within different Habitats of Hydrophytes in Nairobi Dam, Kenya. IORS Journal of Environmental Science, Toxicology and Food Technology 8: 42-45.

4. Kitur EL (2009) A Comparative Study on the Influence of Variations in Environmental Factors on the Phytoplankton Properties of Selected Reservoirs in Central Kenya. PhD Thesis, Kenyatta University, Nairobi, Kenya.

5. Kibet FC (2016) Water Quality and Plant Species Composition of Chemususu Dam, Baringo County, Kenya. Unpublished MSc Thesis, Kenyatta University, Kenya.

6. Grabowska M (2012) The role of a eutrophic lowland reservoir in shaping the composition of river phytoplankton. Ecohydrology and Hydrobiology 12: 231-242.

7. Nasser MK (2013) Ecology and Biodiversity of Freshwater Microalgae in the Selected Areas of the Western Ghats. PhD Thesis, Mahatma Gandhi University, India.

8. Cristina AD, Cervi A, Bona C, Padial AA (2014) Aquatic macrophyte community varies in urban reservoirs with different degrees of eutrophication. Acta Limnologica Brasiliensia 26: 129-142.

9. Misiko FC, Radull J, Sitoki LM, Gichuki J, Andika DO, et al. (2014) Trophic State Indices and Phytoplankton Quotients for the Kisumu Bay, Lake Victoria International Journal of Biological Sciences 1: 53-67.

10. Sidinei MT, Luis BM, Maria SC, Kita KK, Camargo AF (1999) Aquatic macrophytes of Itaipu reservoir, Brazil: survey of species and ecological considerations. Brazilian Archives of Biological Technology 42: 15-22.

11. Araujo T, Leonardo R, Regina P, Maria S (2012) Floristic surveys of aquatic macrophytes in reservoirs in the Agreste zone of Pernambuco State, Brazil. Brazilian Journal of Botany 35: 313-318.

12. Needham J, Needham $P$ (1972) A freshwater guide to the study of freshwater biology. 5th edn. Holden- Day, London.

13. Bronmark C, Hansson LA (2005) The biology of lakes and ponds. Oxford University Press, UK
14. Guiry M (2012) Algae Base. Retrieved: March 25, 2015.

15. Subehi L, Fakhrudin M (2010) Preliminary study of the changes in water temperature at pond Cibuntu. Journal of Ecology and the Natural Environment 3: $72-77$.

16. Lee N, Yee TL, Grinang J (2012) Physico-chemical Characteristics in the Filling Phase of Bakun Hydroelectric Reservoir, Sarawak, Malaysia. International Journal of Applied Science and Technology 2: 92-101.

17. Anyona ND, Abuom OP, Dida OG, Gelder BF, Onyuka O, et al. (2014) Effect of Anthropogenic Activities on Physicochemical Parameters and Benthic Macroinvertebrates of Mara River Tributaries, Kenya. Journal of Environmental Science and Toxicology 2: 098-109.

18. Miheso LR (2008) Effects of Pollution of Motoine River Dams, Kenya. MSc Thesis, Kenyatta University, Nairobi, Kenya.

19. Melakua S, Wondimub T, Damsa R, Moensa L (2007) Pollution status of Tinishu Akari river and its tributaries (Ethiopia) evaluated using physicochemical parameters major ions and nutrients. Journal of Applied Sciences and Environmental Management 21: 13-22.

20. WHO (2011) Guideline for drinking- water quality. 4th edn. World Health Organization, Geneva, Switzerland.

21. Sunkad B (2013) Water quality of Malaprabha river with reference to physicochemical factors near Khanapur town of Belgaum district. International Journal of Innovative Research in Science, Engineering and Technology 2: 930-936.

22. Deshmukh CK, Urkude RN (2014) Physico-chemical and microbial status of Malkhed lake at Chandur railway, District: Amaravati. Journal of life sciences 9: 667-682.

23. Pontivs FW (1990) Water quality and treatment. A Handbook for Community Water Supplies. McGraw-Hill, Inc., USA.

24. Ansar A, Khad F (2005) Eutrophication: An Ecological Vision. The Botanical Review 71: 49-82.

25. Mustapha KM (2008) Assessment of the Water Quality of Oyun Reservoir Offa, Nigeria Using Selected Physico-Chemical Parameters. Turkish Journal of Fisheries and Aquatic Sciences 8: 309-319.

26. WHO (2004) Sulfate in Drinking-water. World Health Organization, Geneva Switzerland

27. Stamenkovic VS, Smiljkov S, Paunovic M, Hristovsk S (2009) The water quality of Mantovo reservoir. Directory of Open Access Journals 61: 501-512.

28. Grimsson F, Zetter R, Halbritter H, Grimm WG (2014) Aponogeton pollen from the Cretaceous and Paleogene of North America and West Greenland: Implications for the origin and palaeobiogeography of the genus. Journal of Science Direct 200: 161-187.

29. Baringo County Government (2014) Baringo County Development Plan 2015/16. Goverment printers, Nairobi, Kenya. 